\title{
Identification of Sub-Acute Ruminal Acidosis (SARA) in Dairy Herds of Pollachi by Analysis of Rumen Fluid and Other Biological Parameters
}

\author{
A.L. Mohammed Ismail*, S. Kavitha, B. Gowri, C.S. Arunaman, \\ B. Nagarajan and S. Vairamuthu \\ Madras Veterinary College, Tamil Nadu Veterinary and Animal Sciences University, \\ Chennai-600 007, Tamil Nadu, India \\ *Corresponding author
}

\section{A B S T R A C T}

Keywords

Sub-Acute Ruminal

Acidosis (SARA), Dairy

Herds, Rumen Fluid

Article Info

Accepted:

20 June 2019

Available Online:

10 July 2019
Sub-acute ruminal acidosis (SARA) is a significant production digestive disorder of dairy cattle. This study conducted a point prevalence study of rumen health status in well-organized dairy herds in pollachi district of Tamil nadu. The study assessed rumen fluid, animal health status, milk production data and biological parameters. A total of sixty cows in early to mid-lactation were sampled from three farms. 8.33 percent of dairy cows managed under semi-intensive system were tested positive for SARA. The study showed that low rumen $\mathrm{pH}$ is prevalent in well managed dairy herds even under semi intensive system of management.

\section{Introduction}

Sub- Acute ruminal acidosis (SARA) also known as chronic acidosis or sub-clinical rumen acidosis (SRA) is a well-recognized digestive disorder found particularly in wellmanaged dairy herds (Enemark, 2009). It is a disorder in cattle fed with high concentrate diets and is characterized by decrease in ruminal $\mathrm{pH}$ below 6.0 that results in lower fibre digestion, changes in rumen fermentation profile, irregular intake and reduced performance (Calsamiglia et al., 2012). Cows might be at greatest risk for SARA immediately postpartum due to diminished size and absorptive capacity of rumen papillae following feeding of lower energy density diets during the dry period (Stone, 2004). Economic losses caused by SARA result from decreased milk production, premature culling and increased death loss.

\section{Materials and Methods}

A total of three well organized dairy herds were selected and a total of sixty dairy cows which are in early to mid-lactation were selected for the study. A total of 45 Jersey Cross cows and $15 \mathrm{HF}$ cross cows were subjected for complete clinical examination and diagnostic procedures. The animals were reared on semi-intensive system with free and 
ad libitum access to grazing pasture. Rumenocentesis was carried out from the ventral sac of the rumen four hours post feeding of Total Mixed Ration (TMR). The commonly used feed ingredients in all three farms were Grounded Rice, Maize, Wheat Bran, Cotton seed Oil cake, Ground Nut oil cake, Paddy Straw and Banana leaves. Forty eight cows were multiparous whereas twelve cows were primiparous. The average milk yield of these cows per day was five litres.

Blood, urine, dung and milk samples were collected from SARA positive animals. Rumen fluid $\mathrm{pH}$ was measured by portable $\mathrm{pH}$ meter whereas urine and dung $\mathrm{pH}$ was measured by SIEMENS The Multistix ${ }^{\circledR} 10$ SG reagent strip and broad range $\mathrm{pH}$ paper immediately after collection. Milk samples were stored at $2^{\circ} \mathrm{C}$ and fat percentage was estimated by Gerber's method three days after collection.

\section{Results and Discussion}

Out of three farms, all the cows in farm I $(n=$ 13) showed a ruminal $\mathrm{pH}$ of 7.5 and were considered SARA negative. Three animals out of twenty two animals in farm II and two animals out of twenty five animals had a $\mathrm{pH}$ of 5.5 suggestive of SARA as shown in Table
1. Two cows were presented with diahorrea and reduced dry matter intake at the time of examination. All five cows were Jersey Cross cows and all of them were multiparous with an average of three calvings. Body score condition of SARA positive cows were 3 and was equal to that of SARA negative cows. Various biochemical parameters from SARA positive animals were listed below in the Table 2. Blood and Serum biochemical parameters revealed no abnormalities except two cows showing decrease in serum calcium concentration average of $8 \mathrm{mg} / \mathrm{dl}$ than the reference range of (10-12 $\mathrm{mg} / \mathrm{dl})$. Urine $\mathrm{pH}$ of all five SARA positive cows was within normal reference value (7-7.5). However, three SARA positive cows showed a decrease in dung $\mathrm{pH}$ (6-6.5) than the reference value of (7.2-7.7). Average milk fat percentage of these cows was 4.52 percent and was within reference values. Thus the prevalence of SARA in well-organized dairy farm in pollachi district is 8.33 percent.

The study demonstrated the prevalence of SARA in pollachi district of Tamilnadu as 8.33 percent in well-organized dairy herds. This was in accordance to the report of O'Grady et al., (2008) who reported that eleven percent of cows were affected with SARA in grazing Irish dairy cows.

Table.1 Incidence of SARA in Pollachi District

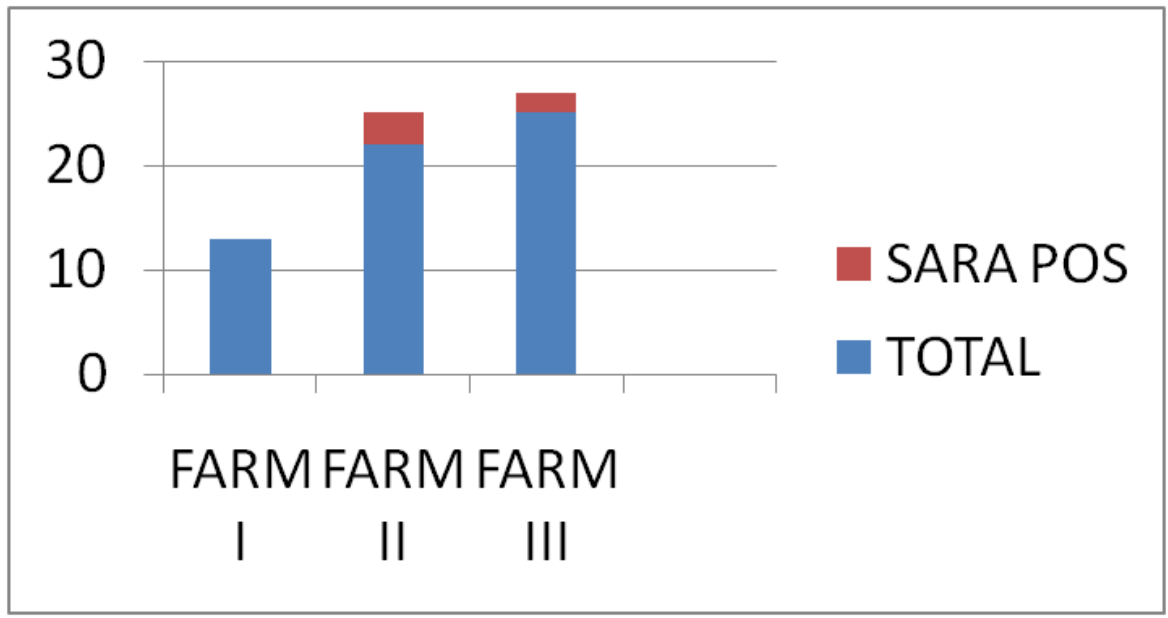


Table.2 Biological parameters of SARA positive dairy cows

\begin{tabular}{|l|l|l|l|l|l|}
\hline ANIMAL & $\begin{array}{l}\text { RUMINAL } \\
\mathrm{pH}\end{array}$ & $\begin{array}{l}\text { SERUM } \\
\text { CALCIUM } \\
(\mathrm{mg} / \mathrm{dl})\end{array}$ & $\begin{array}{l}\text { URINARY } \\
\mathrm{pH}\end{array}$ & DUNG pH & $\begin{array}{l}\text { MILK FAT } \\
\%\end{array}$ \\
\hline $\begin{array}{l}\text { Reference } \\
\text { Values }\end{array}$ & $6-7.2$ & $10-12$ & $7-7.5$ & $7.2-7.7$ & $4.5-4.9$ \\
\hline COW 1 & 5.5 & 8.2 & 7.5 & 8 & 4.6 \\
\hline COW 2 & 5.4 & 11.3 & 7.5 & 6 & 4.3 \\
\hline COW 3 & 5.5 & 10.6 & 7.5 & 6 & 4.5 \\
\hline COW 4 & 5.5 & 7.8 & 7.5 & 6 & 4.6 \\
\hline COW 5 & 5.5 & 11.67 & 7 & 8 & 4.6 \\
\hline
\end{tabular}

The serum concentration of calcium in two SARA positive cows was lower when compared to the normal reference range. Eckel et al., (2016) found the analysis of blood $\mathrm{Ca}$ can been used for diagnosis of SARA, since the translocation of lipopolysaccharides (LPS) during SARA lead to a decrease in this mineral, due to its role in the detoxification of LPS.

Our study found no effect of SARA on milk fat percentage which was in accordance with Kleen et al., (2013) who found that SARA was not associated with milk fat depression in his study in German dairy herds. Two of the five cows had watery dung and three cows had lower dung pH. Morgante et al., (2009) reported drop in fecal $\mathrm{pH}$ which is slightly acidic due to post-ruminal fermentation in the intestines because of a massive outflow of fermentable carbohydrates from the rumen in SARA affected animals.

Although rumen $\mathrm{pH}$ findings were consistent with SARA it was not possible to determine the length of time that the rumen $\mathrm{pH}$ was below the cut-off value used, due to the limitations of a single time-point rumenocentesis sampling.

This study determined the prevalence of SARA in well managed dairy herds in early lactation cows even when they were provided with ad libitum level of grazing pasture. Dung $\mathrm{pH}$, serum calcium level can be used as a useful indicators in the diagnosis of SARA at field levels. However, further studies are needed to determine the duration of decreased $\mathrm{pH}$ in these animals and to evaluate the effect of SARA on changes in rumen microflora during bouts of SARA at field levels.

\section{References}

Calsamiglia, S., M. Blanch, A. Ferret and D. Moya, 2012. Is subacute ruminal acidosis a $\mathrm{pH}$ related problem? Causes and tools for its control. Anim. Feed Sci. Technol. 172 (s 1-2): 42-50.

Eckel, E. F., and B.N Ametaj, 2016. Invited review: Role of bacterial endotoxins in the etiopathogenesis of periparturient diseases of transition dairy cows. $J$. Dairy Sci. 99(8): 1-24.

Enemark, J.M.D., 2009. The monitoring, prevention and treatment of sub-acute ruminal acidosis (SARA): A review. Vet. J. 176(1): 32-43.

Kleen, J.L., L. Upgang and J. Rehage, 2013. Prevalence and consequences of subacute ruminal acidosis in German dairy herds. Acta Vet. Scand. 55(48): 16.

Krause, K.M., and G.R. Oetzel, 2005. Inducing Subacute Ruminal Acidosis in 
Lactating Dairy Cows. J. Dairy Sci. 88(10): 3633-3639.

Morgante, M., M. Gianesella, S. Casella, L. Ravarotto, C. Stelletta and E. Giudice, 2009. Blood gas analyses, ruminal and blood $\mathrm{pH}$, urine and faecal $\mathrm{pH}$ in dairy cows during subacute ruminal acidosis. Comp Clin Pathol. 18(3): 229-232.
O'Grady, L., M.L. Doherty and F.J. Mulligan, 2008. Subacute ruminal acidosis (SARA) in grazing Irish dairy cows. Vet. J. 176(1): 44-49.

Stone, W.C., 2004. Nutritional approaches to minimize subacute ruminal acidosis and laminitis in dairy cattle. J. Dairy Sci. 87(E.Suppl.): 13-26.

\section{How to cite this article:}

Mohammed Ismail, A.L., S. Kavitha, B. Gowri, C.S. Arunaman, B. Nagarajan and Vairamuthu, S. 2019. Identification of Sub-Acute Ruminal Acidosis (SARA) in Dairy Herds of Pollachi by Analysis of Rumen Fluid and Other Biological Parameters. Int.J.Curr.Microbiol.App.Sci. 8(07): 2793-2736. doi: https://doi.org/10.20546/ijcmas.2019.807.341 